\title{
CHEMICAL CHARACTERIZATION OF COMMON MILKWEED (ASCLEPIAS SYRIACA L.) ROOT EXTRACTS AND THEIR INFLUENCE ON MAIZE (Zea mays L.), SOYBEAN (Glycine max (L.) Merr.) AND SUNFLOWER (Helianthus annuus L.) SEED GERMINATION AND SEEDLING GROWTH
}

\author{
POPOV, M. ${ }^{1}$ - PRVULOVIĆ, D. ${ }^{2}$ - ŠUUĆUR, J. ${ }^{2}$ - VIDOVIĆ, S. ${ }^{3}$ - SAMARDŽIĆ, N. ${ }^{1}$ - STOJANOVIĆ, T. \\ - KonstANTINOVIć, B. ${ }^{*}$ \\ ${ }^{I}$ Department of Plant and Environmental Protection, Faculty of Agriculture, University of Novi \\ Sad, Trg Dositeja Obradovića 8, 21102 Novi Sad, Republic of Serbia \\ (phone: +381-21-485-3500) \\ ${ }^{2}$ Department of Field and Vegetable Crops, Faculty of Agriculture, University of Novi Sad, Trg \\ Dositeja Obradovića 8, 21102 Novi Sad, Republic of Serbia \\ (phone: +381-21-485-3500) \\ ${ }^{3}$ Department of Biotechnology and Pharmaceutical Engineering, Faculty of Technology, \\ University of Novi Sad, Bulevar Cara Lazara 1, 21102 Novi Sad, Republic of Serbia \\ (phone: +381-21-485-3619) \\ ${ }^{*}$ Corresponding author \\ e-mail: bojan.konstantinovic@polj.edu.rs; phone: +381-21-485-3315
}

(Received $8^{\text {th }}$ Apr 2021; accepted $19^{\text {th }}$ Jul 2021)

\begin{abstract}
The Asclepias syriaca L. is an invasive weed species which continuously occurs in numerous populations in the ruderal and agricultural land in Serbia. The aim of the study was to examine the antioxidant capacity of the A. syriaca water and methanol extracts and investigate the effects of the selected extracts towards the seed germination, growth, seedlings development and oxidative stress parameters of maize (Zea mays L.), soybean (Glycine max (L.) Merr.) and sunflower (Helianthus annuus L.). The water extract exhibited the higher total tannin content and superoxide free radical scavenging activity, while the methanol extract had a higher antioxidant capacity (measured by FRAP, DPPH and ABTS assays). The total tannin content ranged from 0.252 (methanol extract) to 0.805 (water extract) $\mathrm{mg}$ GAE/g. The water extract showed a significant germination inhibition in the tested plants, while no inhibition was noted in the case of the methanol extract compared with the control. However, both of the tested extracts types significantly reduced shoot and root length in case of all the tested plants.
\end{abstract}

Keywords: Asclepias syriaca, allelopathy, growth inhibition, antioxidant capacity

\section{Introduction}

The common milkweed (Asclepias syriaca L.) occured as an invasive weed in Central and Eastern Europe (Mojzes and Kalapos, 2015) and spread through the extensive areas where it formed new ecosystems (Kelemen et al., 2016). Except being common in abandoned arable land and deforested clearings (Szilassi et al., 2019), as well as on the sand grassland (Bakacsy, 2019), this weed species favours fields and plantations of the agricultural crops (Bakacsy and Bagi, 2020). Many scientific papers confirm the problem of the common milkweed presence in agricultural crops, as well as the cause of the yield reduction of the crops such as: great millet, maize, alfalfa, wheat, sorghum and soybean (Cramer and Burnside, 1982; Bhowmik, 1994; Hartzler and Buhler, 2000). In the past decades in Serbia a continuous presence of the weed species A. syriaca has been 
established in the neglected orchards and vineyards, along the roads and railway lines, as well as on the dams and other ruderal habitats where it most frequently forms uniform associations, or it occurs with other weed species and A. syriaca being the most predominant. From there it spreads to the arable land where it forms "oases", especially in maize, sunflower, soybean, rapeseed, orchards and vineyards (Dolmagić, 2010).

The allelopathic effect of A. syriaca was determined by Le Tourneau et al. (1956) who reported that the water extract of the aerial plant parts at the concentration of $2 \mathrm{~g}$ dry weight per $100 \mathrm{~mL}$ of water inhibits the seed germination, as well as the length of coleoptile and hypocotyl of the Mida wheat. Rasmussen (1975) subsequently found that the water extracts obtained from A. syriaca leaf inhibited the seedling growth of the cultivated sorghum (Sorghum bicolor L.). More recently, Narwal et al. (2000) established that the water extract from the fresh root inhibits the germination of Amaranthus retroflexus L., Chenopodium album L. and Lepidium sativum L. Similarly, Beres and Kazinczi (2000) found that $A$. syriaca water extract reduces the maize germination by $34 \%$, as well as hinders the germination of sunflower and soybean seeds. The same extract was found to induce fresh weight production increase in wheat. According to Szilágyi et al. (2018), the water extract of the $A$. syriaca stem in the concentration of $8 \mathrm{~g} / 100 \mathrm{~mL}$ inhibited the garden cress (Lepidium sativum L.) seed germination, which was also noted in case of the 4 and $8 \mathrm{~g} / 100 \mathrm{~mL}$ concentrations of the leaf water extract.

The common milkweed is a perennial plant with rhizomatic root, which is effective in the vegetative propagation of the plant (Bagi, 2008). Considering its powerful root, large leaf area, effective seed dispersion and clonal spread, drought tolerance (Szitár et al., 2018), as well as the allelopathic properties, this weed can be competitive in case of the other less aggressive plant species (Borders and Lee-Mäder, 2014).

The analyses of the $A$. syriaca chemical composition indicate that the whole plant is the source of polyphenols, oils and hydrocarbon polymers. In 48 A. syriaca populations studied by Campbell (1983) the presence of polyphenol + oil was noted in $4.7-14.4 \%$ of the dry weight samples, while $0.2-1.2 \%$ contained hydrocarbon polymers. In addition, the presence of phenolic acids ( $p$-hydroxybenzoic, $p$-coumaric, protocatechuic and caffeic acid) in $A$. syriaca leaves and flowers was determined by the TLC and HPLC methods. The mentioned author also found that the flowers contain gallic acid, while $\alpha$-resorcylic, vanilla and chlorogenic acid were obtained from the leaves. Sikorska et al. (2000) subsequently established that the conjugated forms of phenolic acids predominate in the A. syriaca plant.

All the aerial plant parts, as well as the root, contain cardenolide glycosides identified as syriobioside, syrioside, syriogenin, xysmalogenin, desglucouzarin, uzarigenin and uzarin, as well as proteins, fitosterols and vitamin $\mathrm{C}$. The resins, waxes, rubber, oil, enzymes, terpens and hydrocarbons are considered to be the main components of the A. syriaca latex (Sikorska et al., 2000). The cardenolides, the bitter-tasting steroids, exhibit toxic effects in animals that consume the plant because they interrupt the Na-K flux in animal cells (Malcolm, 1991).

Given the increasing prevalence of A. syriaca in agroecosystems the aim of this paper was to establish whether the water and methanolic extract of $A$. syriaca root has a negative effect towards the seed germination, the growth and the seedlings development of the most important field crops (maize, sunflower and soybean), and whether the extracts cause oxidative stress for the studied plants. 


\section{Materials and Methods}

\section{Sampling and extracts preparation}

The study was conducted in 2019 by using the root samples of the $A$. syriaca collected in May of the same year from the banks of the Danube $\left(45^{\circ} 15^{\prime} 39^{\prime \prime} \mathrm{N} ; 19^{\circ} 52^{\prime} 00^{\prime \prime} \mathrm{E}\right)$ and dried at $40^{\circ} \mathrm{C}$ for 5 days in the dryer, after which they were ground into powder and stored at $2{ }^{\circ} \mathrm{C}$ until the analysis. The bioassay experiment was carried out two months later, in July, by dispersing the $40 \mathrm{~g}$ of the dry root mass in $1 \mathrm{~L}$ of the distilled water for 24 hours in a shaker (GFL, Schuttelapparate Shakers, Germany, Model 3015) in the dark. The resulting water extract at the concentration level of $0.04 \mathrm{~g} / \mathrm{mL}$, which was marked as WAT, was filtered according to the method described by Chon et al. (2003) and used for making further diluents in order to get 4 final tested concentrations: 0.04, 0.03, 0.02 and $0.01 \mathrm{~g} / \mathrm{mL}$.

The methanolic solution was prepared by dispersing $40 \mathrm{~g}$ of the dry root mass in $1 \mathrm{~L}$ of $95 \%$ methanol at $24^{\circ} \mathrm{C}$ for 24 hours in a shaker (GFL, Schuttelapparate Shakers, Germany, Model 3015) in the dark, followed by filtering using the same procedure as for the WAT. After that the methanol was evaporated to the absolutely dry matter which had been diluted in $1 \mathrm{~L}$ of the distilled water and marked as $0.04 \mathrm{~g} / \mathrm{mL}$ MET. From this dilution, three other diluents were made in order to get 4 final tested concentrations: 0.04 , $0.03,0.02$ and $0.01 \mathrm{~g} / \mathrm{mL}$.

The WAT and the MET extracts were used for further bioassays under the assumption that the WAT extracts absorb more bioactive compounds than the MET extracts, which presumably could be the cause of the greater inhibition of the seed germination and shoot and root length of the tested plants by the WAT extracts.

For the laboratory examination of the allelopathic effect of $A$. syriaca root extracts the soybean (sort Balkan), sunflower (P-251) and maize (hybrid NS 5053) seeds were used. Each extract was diluted with distilled water to obtain the $0.01,0.02,0.03$ and $0.04 \mathrm{~g} / \mathrm{mL}$ concentrations. For each of the four tested concentrations, as well as for the controls, four replicates were done by placing 25 maize, soybean and sunflower seeds separately in the Petri dishes (Ø $12 \mathrm{~mm}$ ) on a filter paper soaked with $8 \mathrm{~mL}$ of the particular extract concentration, i.e. distilled water in case of controls. The whole experiment was carried out twice. Prior to commencing the experiment, all seeds were sterilized via the Voll et al. (2005) method. The seeds were allowed to germinate in a temperature-controlled chamber at $24^{\circ} \mathrm{C}$ during a 12 -hour light period, after which the temperature was reduced to $20^{\circ} \mathrm{C}$ for a 12 -hour dark period, while maintaining the average air humidity at $65 \%$. The allelopathic activity of the A. syriaca root on the maize, soybean and sunflower crops was determined by measuring the seedling shoot and root length (Marinov-Serafimova et al., 2007), as well as by recording the number of the germinated seeds, 7 days after the start of the experiment. After that the plants were collected for the oxidative stress analysis. The germination percentage was calculated using the following formula (Eq.1):

$$
G P(\%)=\frac{G S \times 100}{T S S}
$$

In Equation 1, GP is the germination percentage, $G S$ represents the number of the germinated seeds, while the TSS stands for the total seeds sown. 
Popov et al.: Chemical characterization of common milkweed (Asclepias syriaca L.) root extracts and their influence on maize (Zea mays L.), soybean (Glycine max (L.) Merr.) and sunflower (Helianthus annuus L.) seed germination and seedling growth -4222 -

\section{Chemical analysis of the Asclepias syriaca root extract}

One gram of the dry plant material was extracted overnight with $50 \mathrm{~mL}$ of $70 \%$ methanol. The water extracts were prepared with boiling distilled water. The extracts were centrifuged, filtered and kept in the refrigerator until the analysis.

The contents of the total phenolic (TP) compounds and total tannins (TT) in extracts were determined using a Folin-Ciocalteu colorimetric method (Nagavani and Raghava Rao, 2010). The amount of TP and TT was calculated as a gallic acid equivalent (GAE) from the calibration curve of the gallic acid standard solutions. The obtained results were expressed in milligrams of the gallic acid equivalents per $1 \mathrm{~g}$ of the dry plant weight $(\mathrm{mg}$ $\mathrm{GAE} / \mathrm{g})$.

The ferric-reducing antioxidant power (FRAP) assay was carried out according to the procedure reported by Valentão et al. (2002). The ABTS (2,20-Azino-bis (3Ethylbenzothiazoline-6-Sulfonic Acid)) assay was based on a method described by Miller et al. (1993). The scavenging of the free radicals was evaluated in a DPPH (2,2-diphenyl1-picrylhydrazyl) acetone solution (Lai and Lim, 2011). The degree of the solution discoloration indicates the scavenging efficiency of the added substance. The total antioxidant activity (TAA) of plant extracts was performed by phosphomolybdenum method as reported by Kalaskar and Surana (2014). The standard curves for FRAP, ABTS, DPPH and TAA assays were plotted using the trolox solution. The standard curve was constructed using the different concentrations of the acetone solution of the trolox and the results were expressed as mg trolox equivalents per gram of dry plant material (mg TE/g). The superoxide free radical $\left(\mathrm{O}_{2}\right)$ scavenging activity was carried out by the NBT (nitroblue tetrazolium) test (Kalaskar and Surana, 2014). The results were expressed as the percentage $(\%)$ of the inhibition of $\mathrm{O}_{2}^{-}$production during 15 minutes.

The obtained data are reported as the average values for at least three independent replications for all of the performed assays.

\section{Biochemical analysis of the tested plants}

For the determination of the biochemical parameters $2 \mathrm{~g}$ of the fresh plant material (soybean, sunflower and maize) treated with 0.02 and $0.04 \mathrm{~g} / \mathrm{mL}$ of the WAT, as well as for the control, were homogenized in $10 \mathrm{~mL}$ of the phosphate buffer $(0.1 \mathrm{M}, \mathrm{pH} 7.0)$. After the centrifugation, the supernatants (soybean, sunflower and maize extracts) were used for the biochemical analyses. The biochemical analyses were carried out spectrophotometrically using an UV/VIS spectrophotometer (Thermo Scientific Evolution 220 (USA)).

The superoxide dismutase (SOD) (EC 1.15.1.1) activity was assayed according to the method of Mandal et al. (2008) which was slightly modified by measuring its ability to inhibit the photochemical reduction of the nitro blue tetrazolium (NBT) chloride. One unit of the SOD activity was defined as the amount of enzymes required to inhibit reduction of the NBT by 50\%. The activity of the enzyme was expressed in U/g of fresh weight $(\mathrm{FW})$. The amount of removed superoxide anion radicals was determined by the method of Misra and Fridovich (1972). The total amount of removed superoxide anion radicals was given in nmol $\mathrm{O}_{2}$ per $\mathrm{g}$ of fresh weight $\left(\mathrm{nmol} \mathrm{O}_{2} / \mathrm{g} \mathrm{FW}\right)$. The malondialdehyde (MDA) content, an end product of the lipid peroxidation process, was measured at $532 \mathrm{~nm}$ using the thiobarbituric acid (TBA) test (Mandal et al., 2008). The total amount of the TBA-reactive substances was given in nmol of MDA equivalents per $\mathrm{g}$ of fresh weight (nmol MDA/g FW). 


\section{Statistical analysis}

For biochemical analysis of the tested plants all measurements were performed in triplicates. The values of the biochemical parameters were expressed as the average value \pm standard error and tested by ANOVA followed by the comparison of the average values by Duncan's multiple range test $(p<0.05)$. The data were analyzed using TIBC STATISTICA version 13.5.0.17. The same statistical analysis was used in order to determine the statistical significance of the maize, sunflower and soybean shoot and root length inhibition as the dependent variables and the water and methanol A. syriaca root extract concentrations as the independent variable, as well as for the seed germination of the tested plants as the dependent variable.

\section{Results and Discussion}

\section{Chemical analysis of the Asclepias syriaca root extracts}

The content of the total phenolics, tannins and antioxidant capacity of the water and methanol extracts of the A. syriaca roots are shown in Table 1 where the average values and standard deviation are shown. Regarding the extraction solvent significant differences were found in the content of most measured chemical parameters in the extracts of the A. syriaca roots $(p<0.05)$. No significant differences were observed in TP content and TAA of water and methanol extracts. It is observed that water extracts possess a significantly higher $(p<0.05)$ TT content and a higher superoxide free radical $\left(\mathrm{O}_{2}{ }^{-}\right)$ scavenging activity measured by NBT assay $(51.92 \%)$ compared with the extraction with $70 \%$ methanol (12.39\%). The TT contents in the examined extracts ranged from 0.252 (methanol extract) to 0.805 (water extract) $\mathrm{mg} \mathrm{GAE} / \mathrm{g}$. The methanol extract of the A. syriaca roots possess a higher antioxidant capacity in comparison with the water extract measured by FRAP, DPPH and ABTS assays.

Table 1. The content of the phenolic compounds and the antioxidant capacity of the water and methanol extracts of the A. syriaca roots presented as the average value \pm standard deviation

\begin{tabular}{c|c|c|c|c|c|c|c}
\hline & $\begin{array}{c}\text { Total } \\
\text { phenolics } \\
(\mathbf{m g G A E} / \mathbf{g})\end{array}$ & $\begin{array}{c}\text { Total } \\
\text { tannins } \\
(\mathbf{m g G A E} / \mathbf{g})\end{array}$ & $\begin{array}{c}\text { FRAP } \\
(\mathbf{m g T E} / \mathbf{g})\end{array}$ & $\begin{array}{c}\text { DPPH } \\
(\mathbf{m g T E} / \mathbf{g})\end{array}$ & $\begin{array}{c}\text { ABTS } \\
(\mathbf{m g T E} / \mathbf{g})\end{array}$ & $\begin{array}{c}\text { TAA } \\
(\mathbf{m g T E} / \mathbf{g})\end{array}$ & $\begin{array}{c}\text { NBT assay } \\
(\%)\end{array}$ \\
\hline Water & $2.104 \pm$ & $0.805 \pm$ & $2.441 \pm$ & $1.000 \pm$ & $2.469 \pm$ & $105.184 \pm$ & $79.41 \pm$ \\
extract & $0.057^{\mathrm{a}}$ & $0.073^{\mathrm{a}}$ & $0.058^{\mathrm{a}}$ & $0.322^{\mathrm{a}}$ & $0.162^{\mathrm{a}}$ & $14.202^{\mathrm{a}}$ & $1.52^{\mathrm{a}}$ \\
\hline Methanol & $2.046 \pm$ & $0.252 \pm$ & $3.085 \pm$ & $1.557 \pm$ & $3.069 \pm$ & $94.535 \pm$ & $51.92 \pm$ \\
extract & $0.080^{\mathrm{a}}$ & $0.085^{\mathrm{b}}$ & $0.071^{\mathrm{b}}$ & $0.050^{\mathrm{b}}$ & $0.145^{\mathrm{b}}$ & $3.581^{\mathrm{a}}$ & $1.44^{\mathrm{b}}$ \\
\hline
\end{tabular}

The values followed by the same letter are at the same level of the statistical significance for $\mathrm{p}<0.05$

\section{Effect of Asclepias syriaca root extracts on the bioassay test species}

The applied $A$. syriaca WAT concentrations exhibited a significant germination inhibition in maize, soybean and sunflower seeds in comparison with the control group. The higher WAT concentrations have induced the notable decrease in the percentage of the germinated sunflower and maize seeds. The similar results were obtained by Nádasy et al. (2018) who noticed that $7.5 \%$ water extract of the $A$. syriaca root reduced the maize germination by $20 \%$. 
Nevertheless, the MET extracts have shown no inhibition regarding the seed germination of any of the tested plants (Fig. 1).

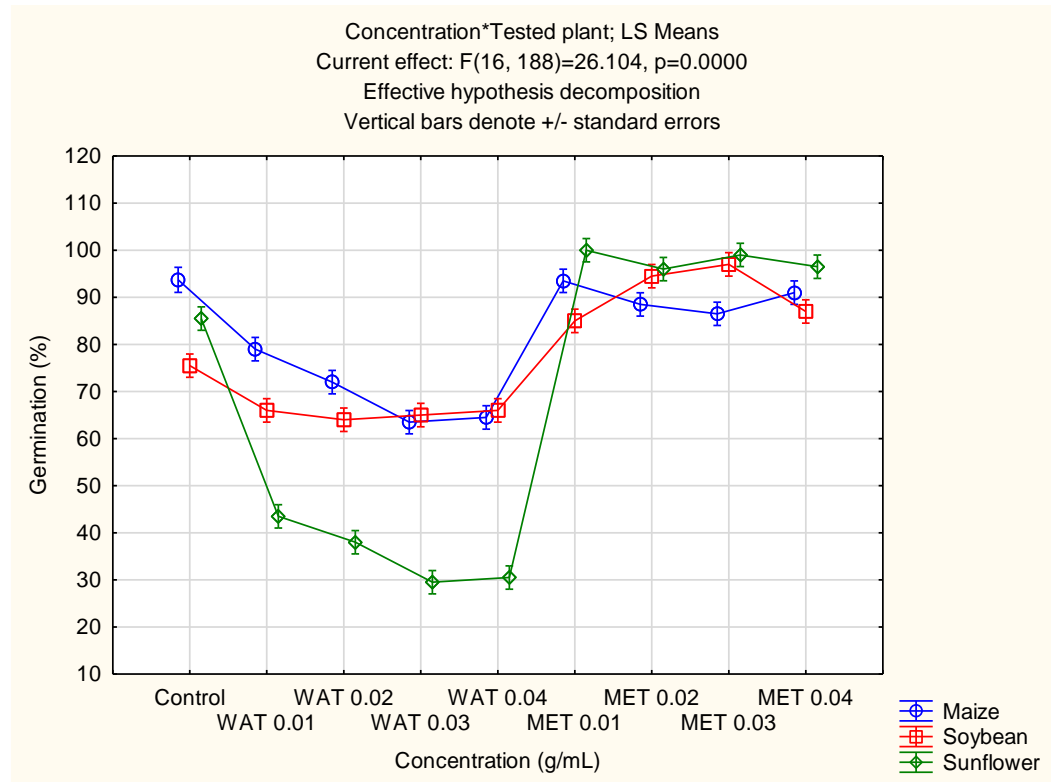

Figure 1. The effect of the Asclepias syriaca root extracts on the maize, soybean and sunflower seeds germination (\%)

The effects of the different WAT and MET concentrations showed the high statistical differences regarding the maize shoot $\left(\mathrm{p}_{\mathrm{sl}}=0.0000\right.$ for $\left.\mathrm{p}<0.01\right)$ and root length $\left(\mathrm{p}_{\mathrm{rl}}=0.0000\right.$ for $\mathrm{p}<0.01)$. Duncan's post hoc test confirmed the tested statistically significant differences and emphasized the similar shoot and root inhibition induced by $0.02,0.03$ and $0.04 \mathrm{~g} / \mathrm{mL}$ of the MET (Fig. 2).

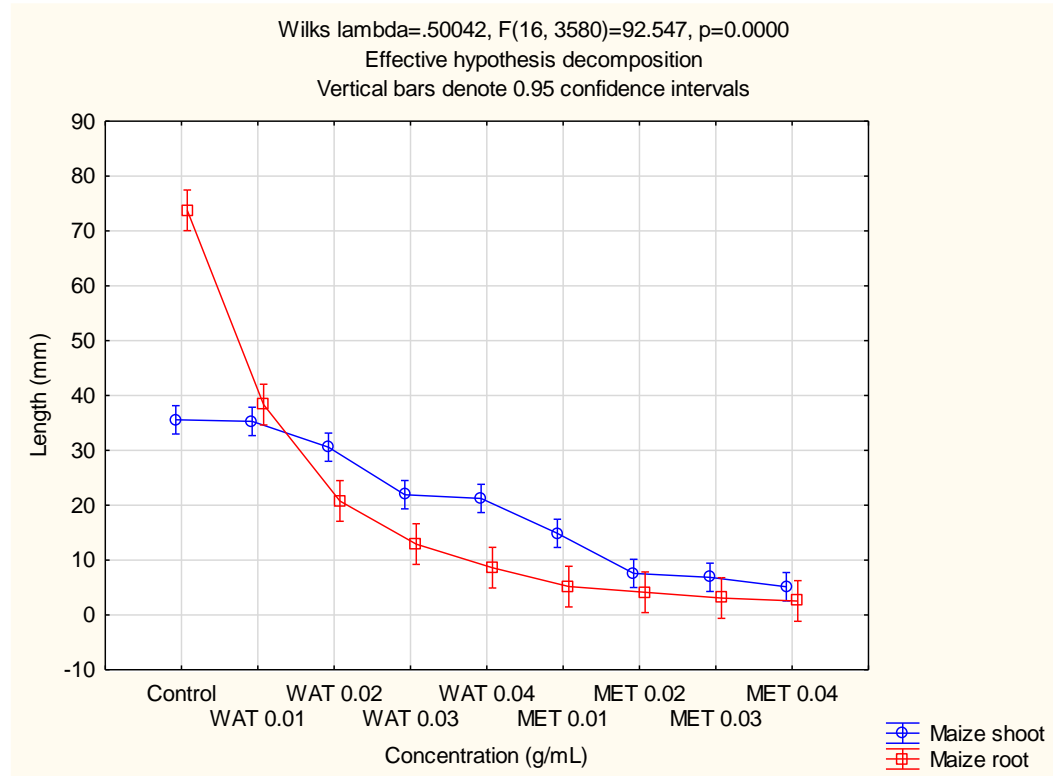

Figure 2. The effect of the water and methanol A. syriaca root extracts on the shoot and root length of the maize 
In case of the soybean, the effects of the different WAT and MET concentrations were similar as in the previous case, where high statistical differences were determined for both the shoot $\left(\mathrm{p}_{\mathrm{sl}}=0.0000\right.$ for $\left.\mathrm{p}<0.01\right)$ and root length $\left(\mathrm{p}_{\mathrm{rl}}=0.0000\right.$ for $\left.\mathrm{p}<0.01\right)$. According to the Duncan's post hoc test high statistically significant differences in shoot and root inhibition were observed for $0.04 \mathrm{~g} / \mathrm{mL}$ of the MET, followed by $0.02,0.03$ and $0.04 \mathrm{~g} / \mathrm{mL}$ of the WAT concentrations (Fig. 3).

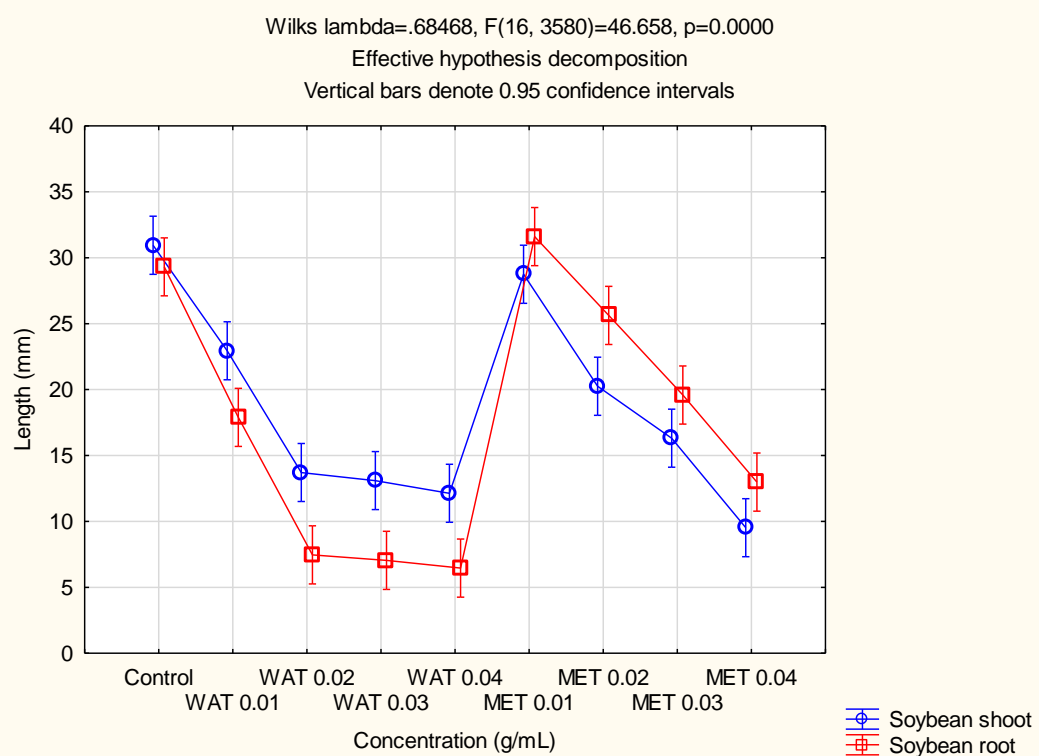

Figure 3. The effect of water and methanol A. syriaca root extracts on shoot and root length of soybean

Comparing the effects of the different WAT and MET concentrations, high statistical differences were observed considering the sunflower shoot $\left(\mathrm{p}_{\mathrm{s} l}=0.0000\right.$ for $\left.\mathrm{p}<0.01\right)$ and root length $\left(\mathrm{p}_{\mathrm{rl}}=0.0000\right.$ for $\left.\mathrm{p}<0.01\right)$. Duncan's post hoc test confirmed the tested statistical significances and highlighted the similar shoot and root inhibition induced by the 0.03 and $0.04 \mathrm{~g} / \mathrm{mL}$ of the WAT and $0.02,0.03$ and $0.04 \mathrm{~g} / \mathrm{mL}$ of the MET (Fig. 4).

\section{Biochemical analysis of the tested plants}

The significant decrease in the activity of the SOD was detected in sunflower seedlings after the treatment with $0.02 \mathrm{~g} / \mathrm{mL}$ of the WAT. On the other hand, in the soybean seedlings the higher concentration of the WAT $(0.04 \mathrm{~g} / \mathrm{mL})$ significantly increased the activity of the SOD. In the maize seedlings there was no significant difference in the activity of the SOD in the treated seedlings compared with the seedlings from the control group.

The total amount of the removed superoxide anion radicals was significantly higher in all treated seedlings after the treatment with the higher concentration $(0.04 \mathrm{~g} / \mathrm{mL})$ of the WAT.

The accumulation of malondialdehyde (MDA) was notably higher in maize and soybean seedlings after the treatment with the higher concentration of the WAT $(0.04 \mathrm{~g} / \mathrm{mL})$. In the maize seedling the amount of MDA was $301 \mathrm{nmol} \mathrm{MDA} / \mathrm{g} \mathrm{FW}$, while the amount of MDA in the soybean seedling was $284 \mathrm{nmol} \mathrm{MDA} / \mathrm{g} \mathrm{FW}$. The 
accumulation of the MDA indicates that $0.04 \mathrm{~g} / \mathrm{mL}$ of the WAT expresses the negative effect against the maize and soybean seedlings inducing oxidative stress accompanied by the induction of the lipid peroxidation process. In the sunflower seedlings there was no significant increase in the lipid peroxidation intensity. The obtained results are shown in Table 2.

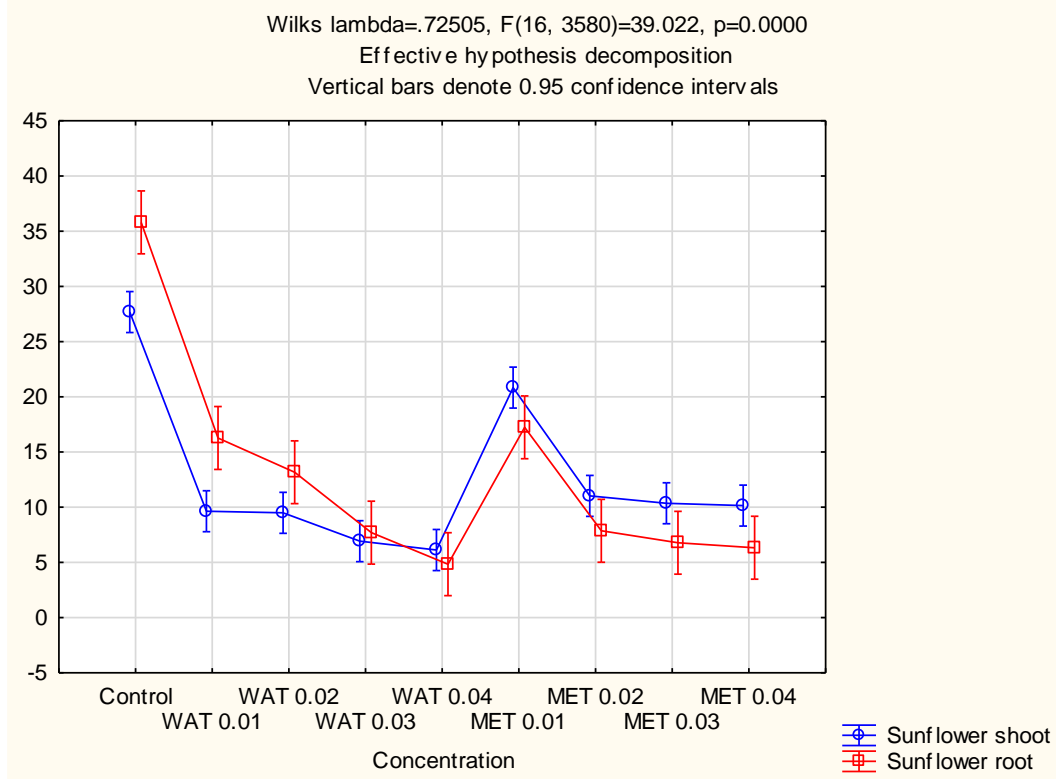

Figure 4. The effect of the A. syriaca water and methanol root extracts concentrations on the sunflower shoot and root length

Table 2. The effect of the two tested concentrations of the Asclepias syriaca water extracts and the control on the activity of the antioxidant enzymes, as well as on the MDA content in the seedlings of the maize, soybean and sunflower presented as the average value \pm standard deviation

\begin{tabular}{|c|c|c|c|c|}
\hline Tested plant & Variable & LP nmol MDA/g FW & SOD U/g FW & nmol O2/g FW \\
\hline \multirow{3}{*}{ maize } & control & $44.273 \pm 0.685^{\mathrm{a}}$ & $44.745 \pm 0.579^{\mathrm{a}}$ & $5.835 \pm 0.568^{\mathrm{a}}$ \\
\hline & $0.02 \mathrm{~g} / \mathrm{mL}$ & $43.151 \pm 3.952^{\mathrm{a}}$ & $47.339 \pm 0.556^{\mathrm{a}}$ & $75.970 \pm 3.905^{\mathrm{b}}$ \\
\hline & $0.04 \mathrm{~g} / \mathrm{mL}$ & $301.613 \pm 4.927^{\mathrm{e}}$ & $46.249 \pm 1.220^{\mathrm{a}}$ & $80.392 \pm 0.810^{\mathrm{b}}$ \\
\hline \multirow{3}{*}{ soybean } & control & $57.511 \pm 4.312^{\mathrm{b}}$ & $1.993 \pm 0.065^{\mathrm{e}}$ & $101.954 \pm 11.459^{b}$ \\
\hline & $0.02 \mathrm{~g} / \mathrm{mL}$ & $66.335 \pm 1.425^{\mathrm{c}}$ & $2.858 \pm 0.260^{\mathrm{e}}$ & $129.852 \pm 82.732^{\mathrm{b}}$ \\
\hline & $0.04 \mathrm{~g} / \mathrm{mL}$ & $284.412 \pm 7.513^{\mathrm{d}}$ & $22.899 \pm 14.134^{b}$ & $241.929 \pm 4.500^{c}$ \\
\hline \multirow{3}{*}{ sunflower } & control & $42.179 \pm 4.094^{\mathrm{a}}$ & $21.507 \pm 0.919^{\mathrm{b}}$ & $88.575 \pm 6.710^{\mathrm{b}}$ \\
\hline & $0.02 \mathrm{~g} / \mathrm{mL}$ & $40.758 \pm 0.648^{\mathrm{a}}$ & $12.333 \pm 3.444^{c}$ & $102.849 \pm 3.683^{b}$ \\
\hline & $0.04 \mathrm{~g} / \mathrm{mL}$ & $40.011 \pm 0.565^{\mathrm{a}}$ & $22.335 \pm 5.096^{\mathrm{b}}$ & $226.798 \pm 19.858^{c}$ \\
\hline
\end{tabular}

The values followed by the same letter are at the same level of the statistical significance for $p<0.05$

The chemical composition analysis of the A. syriaca extract revealed the presence of the phenolic compounds. The total phenolic and tannin content was higher in the A. syriaca root WAT extract compared with MET extract. The negative effect of the WAT on the lipid peroxidation process in maize and soybean seedlings was probably 
caused by the phenolics and other toxic plant secondary metabolites presented in A. syriaca root.

The results of the other authors indicate that the yield losses could be due to phytotoxins produced by A. syriaca. Rasmussen (1975) reported that the water extracts from the fresh $A$. syriaca leaves inhibited the growth of the grain sorghum seedlings. Cramer and Burnside (1982) found that water extracts of A. syriaca shoot and root significantly reduced the germination percentage, hypocotyl length and the radicle length of sorghum. Even though, as allelochemicals, phenols occupy a significant place in the scientific literature (Einhellig, 2004), some characteristics of this group of compounds do not correspond with the allelochemical concept. For example, cinnamic acid is universally present in all higher plants, while benzoic acids are found in all examined Magnoliophyta (Dalton, 1999). Moreover, they are an integral part of the soil to which they are delivered via root secretions, as well as through microbiological activities involved in the degradation of plant residues, which are considered to perform a major impact on the free phenols level in the soil (Blum, 2004). Although the allelopathic effect of the phenols has been extensively studied (Inderjit, 1996), in most cases these compounds are present as a mixture. Similarly, it is likely that more than one compound induces the allelopathy reaction (Einhellig, 2004). Different compounds have varying toxicity, similar modes of action, or affect cellular functions in several different ways, due to which they do not exhibit a typical herbicidal effect. Their individual concentrations in the soil are usually lower than in laboratory conditions and are insufficient for significant allelopathic activity. It is assumed that the intensity of the phenolic compounds allelopathic activity in the natural conditions depends solely on their combination and on the ratio of their quantities, although the possible synergism among the compounds has not yet been proven.

The extensive body of literature on the organic acids possible mechanisms of action, especially phenolic acids, exists (Rice, 1984; Einhellig, 2002; Prasad and Devi, 2002). The available evidence indicates that the root cell membrane is the primary site of action, similar to contact herbicides. This root cell membrane disorder leads to the impairment of its normal functioning and thus results in the interruption of the nutrient and water absorption or energy accumulation (Einhellig, 1995; Blum et al., 1999; Einhellig, 2002; Prasad and Devi, 2002). Hence, there is no universal plant response to the inhibitory concentration of these allelochemicals in relation to, for example, natural stresses. The phenolic acids act as the systemic herbicides since they are absorbed through the roots and gradually translocated throughout the entire plant (Glass and Böhm, 1971; Harper and Balke, 1981; Lehman and Blum, 1999).

\section{Conclusion}

The applied A. syriaca water extract concentrations exhibited a significant germination inhibition in maize, soybean and sunflower seeds, while the MET extracts did not inhibit seed germination of any of the three tested plants. Also, all the concentrations of the studied water extract caused the inhibition to the epicotyl and hypocotyl increase of the three tested plants seedlings, with the exception of the lowest concentration of the WAT extract (0.01) which had no significant influence on the shoot length. The MET extract in all of the tested concentrations inhibited the shoot and root length of the tested plants, with the exception of the lowest concentration of the MET extract (0.01) which had no significant influence on the shoot length of soybean. 
The activity of the SOD was significantly decreased in sunflower seedlings treated with $0.02 \mathrm{~g} / \mathrm{mL}$ of the $A$. syriaca water extract, while it was notably increased in the soybean seedlings treated with $0.04 \mathrm{~g} / \mathrm{mL}$ of the same extract. In case of the maize seedlings a significant difference in the activity of the SOD compared with the control group was not observed.

The total amount of removed superoxide anion radicals was significantly higher in all of the treated seedlings after the treatment with the higher concentration $(0.04 \mathrm{~g} / \mathrm{mL})$ of the $A$. syriaca water extract.

The MDA accumulation was notably higher in maize (301 nmol MDA/g FW) and soybean seedlings ( $284 \mathrm{nmol} \mathrm{MDA} / \mathrm{g} \mathrm{FW}$ ) treated with $0.04 \mathrm{~g} / \mathrm{mL}$ of the $A$. syriaca water extract, which implicates that the mentioned water extract concentration induced oxidative stress, both with the induction of the lipid peroxidation process in maize and soybean seedlings. In the sunflower seedlings there was no significant increase in the lipid peroxidation intensity.

As it was mentioned before, in the natural conditions, the presence of the A. syriaca significantly reduces the crop yield. This adverse effect can be attributed to the competitive relationship between weeds and crops. Still, the levels of the secondary metabolites from the $A$. syriaca root should be subjected to a detailed evaluation, as well as its allelopathic effect in case of other crops.

Considering numerous consequences of the continuous pesticide use the modern agriculture has a task to maintain the quality and the quantity of the crop production while minimizing pesticide application and soil erosion. The concept of allelopathy applied in the modern agricultural production could be of great importance in achieving that important task. Since allelochemicals affect the growth and the yield of the cultivated crops, as well as the present weed populations, the further research considering allelopathy could contribute to finding the alternative ways for the weed management. The possible way of using allelopathy in agriculture implies the production of natural fertilizers with herbicidal activity based on allelochemicals.

\section{REFERENCES}

[1] Bagi, I. (2008): Common milkweed (Asclepias syriaca L.). - In: Botta-Dukát, Z., Balogh, L. (eds.) The Most Important Invasive Plants in Hungary. Hungarian Academy of Sciences, Institute of Ecology and Botany, Vácrátót, Hungary.

[2] Bakacsy, L. (2019): Invasion impact is conditioned by initial vegetation states. Community Ecology 20: 11-19.

[3] Bakacsy, L., Bagi, I. (2020): Survival and regeneration ability of clonal common milkweed (Asclepias syriaca L.) after a single herbicide treatment in natural open sand grasslands. Scientific Reports 10: 14222.

[4] Beres, I., Kazinczi, G. (2000): Allelopathic effects of shoot extracts and residues of weeds on field crops. - Allelopathy Journal 7(1): 93-98.

[5] Bhowmik, P. C. (1994): Biology and control of common milkweed (Asclepias syriaca). In: Duke, S. A. (ed.) Reviews of Weed Science. Weed Science Society of America, Champaign, Illinois.

[6] Blum, U. (2004): Fate of Phenolic allelochemicals in soils - the role of soil and rhizosphere microorganisms. - In: Macias, F. A., Galindo, J. C. G., Molinillo, J. M. G., Cutler, H. G. (eds.) Allelopathy. Chemistry and Mode of Action of Allelochemicals. CRC Press, Boca Raton. 
[7] Blum, U., Shafer, S. R., Lehman, M. (1999): Evidence for inhibitory allelopathic interactions involving phenolic acids in field soils: Concepts vs. an experimental model. Critical Reviews in Plant Sciences 18(5): 673-693.

[8] Borders, B., Lee-Mäder, E. (2014): Milkweeds: A Conservation Practitioner's Guide. - In: Conner, M., Morris, S. (eds.) Plant Ecology, Seed Production Methods, and Habitat Restoration Opportunities. The Xerces Society for invertebrate conservation, Broadway, Portland.

[9] Campbell, T. A. (1983): Chemical and agronomic evaluation of common milkweed, Asclepias syriaca. - Economic botany 37(2): 174-180.

[10] Chon, S. U., Kim, Y. M., Lee, J. C. (2003): Herbicidal potential and quantification of causative allelochemicals from several Compositae weeds. - Weed research 43(6): 444-450.

[11] Cramer, G. L., Burnside, O. C. (1982): Distribution and interference of common milkweed (Asclepias syriaca) in Nebraska. - Weed Science 30(4): 385-388.

[12] Dalton, B. R. (1999): The occurrence and behavior of plant phenolic acids in soil environments and their potential involvement in allelochemical interference interactions: Methodological limitations in establishing conclusive proof for allelopathy. - In: Inderjit, K. M., Dakshimi, M., Foy, L. C. (eds.) Principle and Practices in Plant Ecology Allelochemical Interactions. CRC Press LLC, Boca Raton.

[13] Dolmagić, A. (2010): Preliminarna ispitivanja o mogućnosti suzbijanja ciganskog perja (Asclepias syriaca L.) - u usevu soje. - Biljni lekar 38(1): 42-49.

[14] Einhellig, F. A. (1995): Allelopathy - Current Status and Future Goals. - In: Inderjit, K. M., Dakshini, M., Einhellig, F. A. (eds.) Allelopathy: Organisms, Processes and Applications. ACS Symposium Series, American Chemical Society, Washington DC.

[15] Einhellig, F. A. (2002): The physiology of allelochemical action: clues and views. - In: Reigosa, M. J., Pedrol, N. (eds.) Allelopathy: From Molecules to Ecosystems. Science Publishers, Inc., Enfield.

[16] Einhellig, F. A. (2004): Mode of allelochemical action of phenolic compounds. - In: Macias, F. A., Galindo, J. C. G., Molinillo, J. M. G., Cutler, H. G. (eds.) Allelopathy. Chemistry and Mode of Action of Allelochemicals. CRC Press, Boca Raton.

[17] Glass, A. D. M., Böhm, B. A. (1971): The uptake of simple phenols by barley roots. Planta 100(2): 93-105.

[18] Harper, J. R., Balke, N. E. (1981): Characterization of the inhibition of $\mathrm{K}^{+}$absorption in oat roots by salicylic acid. - Plant Physiology 68(6): 1349-1553.

[19] Hartzler, R. G., Buhler, D. D. (2000): Occurrence of common milkweed (Asclepias syriaca) in cropland and adjacent areas. - Crop Protection 19(5): 363-366.

[20] Inderjit, K. (1996): Plant phenolics in allelopathy. - The Botanical Review 62(2): 186-202.

[21] Kalaskar, M. G., Surana, S. J. (2014): Free radical scavenging, immunomodulatory activity and chemical composition of Luffa acutangula var. Amara (Cucurbitaceae) pericarp. Journal of the Chilean Chemical Society 59(1): 2299-2302.

[22] Kelemen, A., Valkó, O., Kröel-Dulay, G., Deák, B., Török, P., Tóth, K., Miglécz, T., Tóthmérész, B. (2016): The invasion of common milkweed (Asclepias syriaca) in sandy old-fields - is it a threat to the native flora? - Applied Vegetation Science 19: 218-224.

[23] Lai, H. Y., Lim, Y. Y. (2011): Evaluation of antioxidant activities of the methanolic extracts of selected ferns in Malaysia. - International Journal of Environmental Science and Development 2(6): 442-447.

[24] Le Tourneau, D., Fails, G. D., Heggeness, H. G. (1956): The effect of water extracts of plant tissue on germination of seeds and growth of seedlings. - Weeds 4(4): 363-368.

[25] Lehman, M. E., Blum, U. (1999): Evaluation of ferulic acid uptake as a measurement of allelochemical dose: effective concentrations. - Journal of Chemical Ecology 25(11): 2585-2600.

[26] Malcolm, S. B. (1991): Cardenolide-mediated interactions between plants and herbivores. - In: Rosenthal, G. A., Berenbaum, M. R. (eds.) Herbivores: Their Interactions with Secondary Metabolites. Academic Press, San Diego, CA, USA. 
[27] Mandal, S., Mitra, A., Mallick, N. (2008): Biochemical characterization of oxidative burst during interaction between Solanum lycopersicum and Fusarium oxysporum f. $s p$. lycopersici. - Physiological and Molecular Plant Pathology 72(1): 56-61.

[28] Marinov-Serafimova, P., Dimitrova, T. S., Golubinova, I., Ilieva, A. (2007): Study of suitability of some solutions in allelopathic researches. - Herbologia 8(1): 1-10.

[29] Miller, N. J., Rice-Evans, C., Davies, M. J., Gopinathan, V., Milner, A. (1993): A novel method for measuring antioxidant capacity and its application to monitoring and antioxidant status in premature neonates. - Clinical Science 84: 407-412.

[30] Misra, H. P., Fridovich, I. (1972): The Role of Superoxide Anion in the Autoxidation of Epinephrine and a Simple Assay for Superoxide Dismutase. - Journal of Biological Chemistry 247: 3170-3175.

[31] Mojzes, A., Kalapos, T. (2015): Plant-Derived Smoke Enhances Germination of the Invasive Common Milkweed (Asclepias syriaca L.). - Polish Journal of Ecology 63(2): 280-285.

[32] Nádasy, E., Pásztor, G., Béres, I., Szilágyi, G. (2018): Allelopathic effects of Abutilon theophrasti, Asclepias syriaca and Panicum ruderale on maize. - Tagungsband 28. Deutsche Arbeitsbesprechung über Fragen der Unkrautbiologie und -bekämpfung, 27.02.01.03.2018, Braunschweig, Deutschland, pp. 453-457.

[33] Nagavani, V., Raghava Rao, T. (2010): Evaluation of antioxidant potential and identification of polyphenols by RP-HPLC in Michelia champaca flowers. - Advances in Biological Research 4(3): 159-168.

[34] Narwal, S. S., Hoagland, R. E., Dilday, R. H., Reigosa, M. J. (2000): Allelopathy in Ecological Agriculture and Forestry. - Proceedings of the III International Congress on Allelopathy in Ecological Agriculture and Forestry, 18-21 August, Dharwad, India, pp. 1-9.

[35] Prasad, M. N. V., Devi, S. R. (2002): Physiological basis for allelochemical actions of ferulic acid. - In: Reigosa, M. J., Pedrol, N. (eds.) Allelopathy: From Molecules to Ecosystems. Science Publishers, Inc., Enfield.

[36] Rasmussen, J. A. (1975): Non-competitive effects of common milkweed, Asclepias syriaca L., on germination and growth of grain sorghum. - The American Midland Naturalist Journal 94(2): 478-483.

[37] Rice, E. L. (1984): Allelopathy. - Academic Press, Orlando.

[38] Sikorska, M., Matławska, I., Głowniak, K., Zgórka, G. (2000): Qualitative and quantitative analysis of phenolic acid in Asclepias syriaca L. - Acta Poloniae Pharmaceutica 57(1): 6972.

[39] Szilágyi, A., Radócz, L., Tóth, T. (2018): Allelopathic effect of invasive plants (Eriochloa villosa, Asclepias syriaca, Fallopia x bohemica, Solidago gigantea) on seed germination. - Acta Agraria Debreceniensis (74): 179-182.

[40] Szilassi, P., Szatmári, G., Pásztor, L., Árvai, M., Szatmári, J., Szitár, K., Papp, L. (2019): Understanding the Environmental Background of an Invasive Plant Species (Asclepias syriaca) for the Future: An Application of LUCAS Field Photographs and Machine Learning Algorithm Methods. - Plants 8(12): 593.

[41] Szitár, K., Kröel-Dulay, G., Török, K. (2018): Invasive Asclepias syriaca can have facilitative effects on native grass establishment in a water-stressed ecosystem. - Applied Vegetation Science 21: 607-614.

[42] Valentão, P., Fernandes, E., Carvalho, F., Andrade, P. B., Seabra, R. M., Bastos. M. L. (2002): Antioxidative properties of cardoon (Cynara cardunculus L.) infusion against superoxide radical, hydroxyl radical, and hypochlorus acid. - Journal of Agricultural and Food Chemistry 50(17): 4989-4993.

[43] Voll, E., Voll, C. E., Filho, R. V. (2005): Allelopathic effects of aconitic acid on wild poinsettia (Euphorbia heterophylla) and morningglory (Ipomoea grandifolia). - Journal of Environmental Science and Health Part B 40(1): 69-75. 